\title{
Ectopic production of guanosine penta-and tetraphosphate can initiate early developmental gene expression in Myxococcus xanthus
}

\author{
Mitchell Singer and Dale Kaiser ${ }^{1}$ \\ Departments of Biochemistry and of Developmental Biology, Beckman Center for Molecular and Genetic Medicine, Stanford \\ University School of Medicine, Stanford, California 94305-5427 USA
}

\begin{abstract}
Amino acid or carbon limitation is sufficient to initiate fruiting body development in Myxococcus xanthus. In both Escherichia coli and $M$. xanthus the levels of guanosine $3^{\prime}$-di-5'-(tri)di-phosphate nucleotides [(p)ppGpp] rise transiently when cells are starved for amino acids or carbon. Ectopic increase in the intracellular concentration of (p)ppGpp was achieved in $M$. xanthus by introducing a copy of the $E$. coli relA gene, whose product catalyzes pyrophosphate transfer from ATP- to GTP-forming PppGpp. The $E$. coli RelA protein was detected in these $M$. xanthus strains, and a rise in (p)ppGpp was observed chromatographically. This increase in the intracellular (p)ppGpp levels was sufficient to activate developmentally specific gene expression. Although (p)ppGpp is made from GTP, the intracellular GTP pool from these strains was not significantly decreased. Moreover, when the GTP pool was lowered by either of two specific inhibitors of GTP synthesis, mycophenolic acid or decoyinine, development was not induced. These results suggest that $M$. xanthus cells can assess their nutritional status by monitoring the internal availability of amino acids through (p)ppGpp levels.
\end{abstract}

[Key Words: Guanosine tetraphosphate; Myxococcus xanthus development; RelA; gene expression]

Received February 15, 1995; revised version accepted May 24, 1995.

Starvation at high cell density induces Myxococcus xanthus to form a multicellular structure, the fruiting body (Dworkin and Kaiser 1985; Kaiser 1989). Inside the fruiting body, individual rod-shaped cells differentiate into environmentally resistant and metabolically quiescent myxospores. Only $10 \%$, and if starvation is severe, $<1 \%$, of the cells initiating the developmental program survive as spores (Wireman and Dworkin 1977). Therefore, to maximize survival, cells need to evaluate starvation and anticipate nutrient exhaustion before they undertake fruiting body development. Because successful fruiting body formation involves the participation of $\sim 100,000$ cells, individual cells must also evaluate the nutritional status of the other cells belonging to the same population.

Previous work has shown that $M$. xanthus cells respond to their neighboring cells through a series of extracellular signals. One of the earliest of these extracellular signals is A-signal, appearing in the culture medium at $\sim 1 \mathrm{hr}$ and peaking at $3 \mathrm{hr}$ after induction by starvation (Kuspa et al. 1986, 1992a). Cells respond to A-signal by expressing a series of genes and by initiating

${ }^{1}$ Corresponding author. aggregation (Kuspa et al. 1986; Kroos and Kaiser 1987). A-signal consists of a mixture of amino acids (the six most active amino acids include Tyr, Pro, Phe, Trp, Leu, and Ile) each of which are released at micromolar concentrations. The amount of A-signal released by cells is proportional to cell number and has been proposed to act as a cell density signal (Kuspa et al. 1992b). To induce these cellular responses a threshold extracellular level of $\sim 10 \mu \mathrm{M}$ A-signal amino acids are required, a concentration too low to support cell growth. However, the addition of higher concentrations of A-signal amino acids $(>7 \mathrm{~mm})$, which are sufficient to allow net protein synthesis and cell growth, actually prevent the expression of A-signal-dependent genes (Kuspa et al. 1992a).

In nature $M$. xanthus is bacteriolytic, utilizing amino acids, peptides, and proteins but not the carbohydrates of the bacteria on which it feeds (Dworkin 1962; Bretscher and Kaiser 1978). Because amino acids serve as its carbon and energy source, as well as substrates for protein synthesis, $M$. xanthus could in theory assess its overall nutritional status by monitoring the levels of its internal amino acid pools.

An examination of conditions that induce fruiting body development demonstrated that limitation of any amino acid is capable of initiating development. Thus, 
starvation for essential amino acids, deprivation of required amino acids from an auxotroph, or addition of amino acid analogs that inhibit the acylation of tRNAs, for example, serine hydroximate or tyrosinol, induce fruiting body development (Manoil and Kaiser 1980a). All conditions that induced development were also found to increase the intracellular concentration of (p)ppGpp (Manoil and Kaiser 1980b). Moreover, M. xanthus was found to arrest rRNA synthesis in response to amino acid limitation (M. Singer, unpubl.).

In Escherichia coli and Salmonella, (p)ppGpp appears to couple rRNA synthesis and the rate of cell growth to the cell's capacity for protein synthesis (for review, see Cashel and Rudd 1987). It has been suggested that $M$. xanthus cells could monitor their capacity for protein synthesis as a sensitive indicator of the availability of nutrient by means of the (p)ppGpp level (Manoil and Kaiser $1980 a, b)$. Although the initiation of development correlates with an elevation of $(\mathrm{p}) \mathrm{ppG} \mathrm{pp}$, direct evidence that elevation of (p)ppGpp levels is the initiator of development is lacking. One could argue that the elevation of (p)ppGpp and the expression of developmentally regulated genes are both consequences of another initiating event, such as the lowering of the intracellular GTP pool, as in the case of Bacillus subtilis endospore formation (Ochi et al. 1982). The opportunity to test directly whether (p)ppGpp acts as an initiation signal in $M$. xanthus was offered by the cloning of the relA gene from $E$. coli (Schreiber et al. 1991). Here, we report a direct test of the hypothesis that $M$. xanthus uses a rise in the level of (p)ppGpp to initiate fruiting body development by introducing a regulatable copy of the relA gene from $E$. coli into $M$. xanthus.

\section{Results}

\section{Ectopic synthesis of (p)ppGpp}

When $M$. xanthus cells are shifted from a nutrient medium rich in amino acids and peptides to a buffered salts medium with no utilizable carbon or nitrogen source, the cells initiate a developmental program that culminates in the formation of fruiting bodies within $24 \mathrm{hr}$. Within $30 \mathrm{~min}$ after starvation, the cells respond by increasing their intracellular concentration of ppGpp 10to 12 -fold. Within $2 \mathrm{hr}$ the ppGpp level begins to decay, as shown in Figure 1. However, this 2-hr ppGpp level is higher than the level during growth. These data agree with Manoil's previous observations that after an abrupt starvation, ppGpp levels rise 10- to 15-fold within 30 min and then decrease to a new level 4- to 6-fold higher than the prestarvation level that persists at least to $7 \mathrm{hr}$ after starvation (Manoil and Kaiser 1980a; Manoil 1982). These data illustrate the correlation between starvation conditions that are able to induce fruiting body development and a rise in the intracellular concentration of (p)ppGpp.

To test whether a rise in the intracellular (p)ppGpp concentration might also be sufficient to initiate fruiting body development in $M$. xanthus, the synthesis of

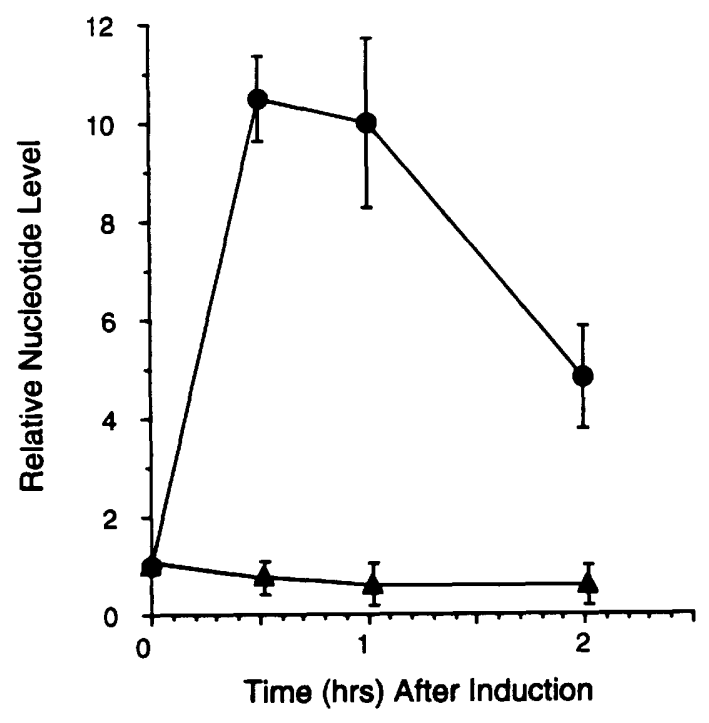

Figure 1. Resposnse of ppGpp and GTP to a nutritional down shift. Guanosine $5^{\prime}$-triphosphate and guanosine $5{ }^{\prime}$-di-3'-diphosphate nucleotides were separated by TLC during starvation. One-milliliter samples of a culture were removed before the shift (preshifted reference sample, time 0) from $1 \%$ casitone (CTT) to TPM buffer, and at 0 (preshifted reference sample), 30, 60 , and $120 \mathrm{~min}$ after shift. Nucleotides were extracted and quantified as described in Materials and methods. (A) GTP; $\mid$ ppGpp. Nucleotide levels are expressed relative to the preshifted level and represent the average of three independent experiments. Absolute nucleotide concentrations at time 0 for cells growing in CTT were $4 \times 10^{-12}$ mole/Klett unit for GTP and $1.5 \times 10^{-13} \mathrm{~mole} / \mathrm{Klett}$ unit for $\mathrm{ppGpp}$ and are designated as a relative nucleotide level of 1 .

(p)ppGpp was artificially induced without nutrient limitation. For this purpose, the E. coli relA gene, which encodes (p)ppGpp synthetase I (Metzger et al. 1988), was placed under the control of the $M$. xanthus light-inducible carQRS promoter (Hodgson 1993) and introduced into $M$. xanthus cells. Two sets of plasmids incorporating the carQRS promoter were constructed: The first set, plasmids pMS132 and pMS134, contain the E. coli relA gene under the transcriptional control of the carQRS promoter; the second set, plasmids pMS131 and pMS133, are identical to pMS132 and pMS134, respectively, except that they lack the E. coli relA gene. All four plasmids are designed to integrate at the chromosomal $\mathrm{Mx} 8$ prophage attachment site (Mx8 attB) (Orndorff et al. 1983; Stellwag et al. 1985) and encode either kanamycin (pMS131 and pMS132) or tetracycline resistance (pMS133 and pMS134) to enable selection of the plasmid. $M$. xanthus DK101 strains containing either pMS131 or pMS132 were examined before and after exposure to inducing levels of light for synthesis of $E$. coli RelA protein and (p/ppGpp. These experiments were conducted in a rich nutrient medium (CTT) that supported exponential growth with a mean doubling time of $6 \mathrm{hr}$ at $33^{\circ} \mathrm{C}$.

When exponential phase $M$. xanthus cells carrying the E. coli relA gene (pMS132) were exposed to light, the 
synthesis of E. coli RelA protein was detected in Western blots probed with antibody raised against E. coli RelA protein. After inducing by light, a single strong band having an apparent molecular mass of $85 \mathrm{kD}$, the size reported for E. coli RelA protein (Schreiber et al. 1991), was observed. This protein was first detected at $2 \mathrm{hr}$ after exposure to light, rose to a maximum at $5 \mathrm{hr}$, and was still present $10 \mathrm{hr}$ after exposure to light (Fig. 2A, where only the 0 -, and 5-hr data are shown). This time course agreed with previous reports of expression driven by the carQRS promoter (Hodgson 1993). At its maximum the total amount of $E$. coli RelA protein constituted $<1 \%$ of the total cell protein measured on Coomassie bluestained gels (data not shown). The proteins evident as faint bands in the Western blot of Figure 2A that migrated as higher molecular weight species than $E$. coli RelA and that reacted with the antiserum are most likely $M$. xanthus or plasmid-encoded proteins, as they were also present in cells carrying the control (no relA) plasmid pMS131 with and without light. The increase in $E$. coli RelA protein was accompanied by an increase in the levels of both pppGpp and ppGpp (Fig. 2B,C). The amounts of ppGpp, GTP, and ATP, each presented relative to its preinduction level, were measured chromatographically in strain DK101 carrying pMS132 (Fig. 2C). After light induction the ppGpp level showed a steady increase up to $4 \mathrm{hr}$ at which time it had risen five- to eightfold above preinduction. No significant changes were detected in the levels of GTP or ATP after exposure to light. Although some expression of E. coli RelA protein was detected by antibody during growth (Fig. 2A, 0 $\mathrm{hr})$, it was apparently insufficient to raise the level of ppGpp; this was evident by comparison of pMS131 and pMS132 (Fig. 2C; data not shown).

A decrease in the rate of $M$. xanthus growth correlating with the elevation of ppGpp was evident at $2 \mathrm{hr}$ (Fig. 2D). Growth was not inhibited in strains carrying the control plasmid pMS131 (Fig. 2D) or in either set of strains grown in the dark (data not shown). To test whether ppGpp accumulation was specifically correlated with expression of $E$. coli RelA or if any foreign protein could have the same effect, we introduced the $1 a c Z$ gene under the control of the carQRS promoter. Strains containing plasmid pDAH217 (Hodgson 1993) were exposed to light, $\beta$-galactosidase activity measured, and the nucleotides extracted and analyzed. Although $\beta$-galactosidase activity rose 20 -fold within $6 \mathrm{hr}$ after light induction, ppGpp levels increased at most $30 \%$ over a parallel culture without the $1 a c Z$ gene (data not shown). Thus, a substantial increase in ppGpp level was specifically associated with production of the E. coli RelA protein; production of an even larger amount of $E$. coli $\beta$-galactosidase protein in $M$. xanthus $\{1 \%-5 \%$ of total protein based on Coomassie blue-stained gels after $6 \mathrm{hr}$ of induction; data not shown) had much less effect. The growth response in $M$. xanthus was similar to that in $E$. coli when
A

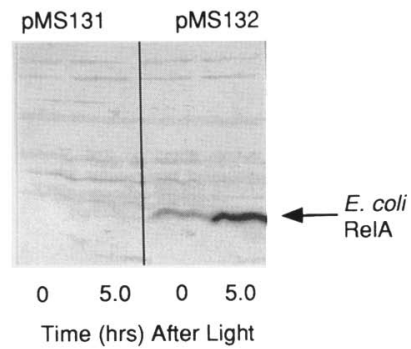

C

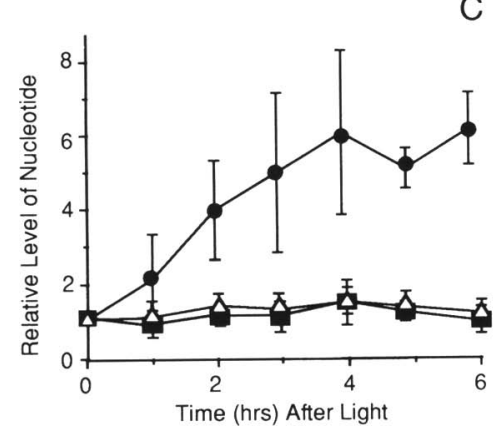

Figure 2. Expression of E. coli relA and (p)ppGpp synthesis in M. xanthus. M. xanthus strains carrying either pMS131 or pMS 132 were grown in CTT at $33^{\circ} \mathrm{C}$ in the dark. Note that the ordinate is a logarithmic scale. At the time indicated by the arrow, exponentially growing cells were exposed to light as described in Materials and methods. (A) Western blots of E. coli RelA protein from strains DK101 pMS132, and DK101 pMS131 before light induction, time 0 , and $5 \mathrm{hr}$ after light induction. The arrow indicates the band corresponding to $E$. coli RelA protein. $(B)$ One-dimensional TLC of extracts of strains DK101 pM131 and DK101 pMS132, with equal number of counts loaded at the origin in each lane. $(C)$ Incorporation of ${ }^{32} \mathrm{P}$ into ATP, GTP, and ppGpp. ( $\triangle)$ ATP; ( $)$ GTP; (O) ppGpp. The level of each nucleotide is expressed relative to its level before exposure to light. The points are averaged over three independent experiments. The absolute nucleotide levels at time 0 /growing cells) for ATP, GTP, and ppGpp were $3 \times 10^{-11} \mathrm{~mole} / \mathrm{Klett}, 4 \times 10^{-12} \mathrm{~mole} /$ Klett, and $1.5 \times 10^{-13} \mathrm{~mole} / \mathrm{Klett}$, respectively, and are designated as a relative nucleotide level of 1 , (D) Growth curve of strains DK101 pMS132 (vector plus E. coli relA) (ם), and DK101 pMS131 (vector alone) ( $\square$ ). 
the $r e l A$ gene was overexpressed: first, an increase in the intracellular (p)ppGpp concentration, and then a decrease in the rate of growth (Schreiber et al. 1991).

To further document the (p/ppGpp synthetase I activity of $E$. coli RelA protein in $M$. xanthus, (p)ppGpp synthesis was measured in extracts of $M$. xanthus and $E$. coli cells. The synthetic capacity of partially purified (p)ppGpp synthetase I (RelA) from $E$. coli was activated by either an $E$. coli ribosome fraction or an $M$. xanthus ribosome fraction (Table 1). Moreover, the level of activation by the $M$. xanthus ribosome fraction was as high as by E. coli ribosomes. Similarly, E. coli ribosomes were found to activate a (p)ppGpp synthetase activity from $M$. xanthus extracts (Table 1). These data support the in vivo plasmid experiments by showing that $E$. coli RelA protein can function efficiently with $M$. xanthus ribosomes in vitro. The lower (p)ppGpp synthesis in $M . x a n-$ thus extracts as opposed to $E$. coli extracts has not been explored further.

\section{Expression of early developmentally regulated transcriptional lacZ fusions}

The amount of light required to activate the carQRS promoter inhibits the development of spores in fruiting bodies of $M$. xanthus (Li et al. 1992). However, the developmental block induced by light is not evident until 6-10 hr after initiation. Apparently the inhibition by light occurs between this time and $20 \mathrm{hr}$ when sporulation starts. This should allow time to observe early initiation stages of the program of fruiting body development, at least those prior to $6 \mathrm{hr}$. Initiation of development was measured by the expression of early developmentally-specific gene fusions (Kroos and Kaiser 1984): in particular, two transcriptional lacZ fusions, $\Omega 4408$ and $\Omega 4469$, which are expressed beginning at $0-1$ and $4 \mathrm{hr}$, respectively, after the initiation of development by starvation (Kroos et al. 1986).

Expression of $\beta$-galactosidase from the above two transcriptional fusions was measured in isogenic strains of $M$. xanthus carrying either integrated pMS134 (containing $E$. coli relA) or pMS133 (identical to pMS134 but lacking $E$. coli relA) (Fig. 3A). $\beta$-Galactosidase activity increased after exposure to light in the strains carrying the $E$. coli relA gene but not in the control strains. After light induction of $E$. coli RelA protein the level of $\beta$-galactosidase expression from the $\Omega 4408$ and $\Omega 4469$ reporter fusions reached at least $70 \%$ of the level of $\beta$-ga- lactosidase expression observed following starvation (Fig. 3B). No increase in expression from these reporter fusions was observed when experimental, and the no $E$. coli relA control strains were cultured in the dark in the presence of nutrients (data not shown), demonstrating that induction of $\beta$-galactosidase expression from these fusions requires expression of $E$. coli relA. Nor did exposure to light inhibit $\beta$-galactosidase expression when the $\Omega 4408$ and $\Omega 4469$ fusion-containing strains were starved as well as illuminated (data not shown). The absence of any inhibition by light of $\Omega 4408$ and $\Omega 4469$ expression in this control experiment supports the expectation that the light-inhibited step occurs after $6 \mathrm{hr}$. Moreover, the time course of $\beta$-galactosidase expression from $\Omega 4408$ and $\Omega 4469$ after light induction was similar in each case to that observed after induction by starvation in these strains (Fig. 3B). The light-induced expression of $\Omega 4469$ occurred later than that of $\Omega 4408$.

\section{Expression from an A-factor-dependent fusion}

Intercellular A-signaling is required to initiate aggregation (Kuspa et al. 1986) and for expression of all but a few of the developmentally regulated reporter fusions including $\Omega 4408$ and $\Omega 4469$, which are among those A-independent few (Kroos and Kaiser 1987). The $\Omega 4521$ fusion is A-signal-dependent, and its expression is initiated about 2 hr after starvation (Kuspa et al. 1986). Because this expression time lies within the interval between $\Omega 4408$ and $\Omega 4469, \Omega 4521$ offers access to the early A-signal-dependent segment of the developmental program.

Isogenic $M$. xanthus strains carrying the $\Omega 4521$ fusion and either pMS134 or pMS133 were assayed for $\beta$-galactosidase expression after light induction in the presence of nutrients. $\beta$-Galactosidase activity from the $\Omega 4521$ fusion increased within 3-4 hr after induction by light in the E. coli relA-containing strain (pMS134), whereas the control strain (pMS133) failed to increase (Fig. 4A). The time course of $\beta$-galactosidase expression was similar following the ectopic expression of $E$. coli RelA and following starvation, though possibly delayed for an hour (Fig. 4B). Induction of $\beta$-galactosidase activity from the $\Omega 4521$ fusion following exposure to light was at least three- to fivefold higher than the growth level.

Conditions that regulate expression of the $\Omega 4521 \mathrm{fu}$ sion include starvation and the level of A-factor (Kuspa et al. 1986; Kaplan et al. 1991). E. coli Rel A expression was also examined in strains unable to produce A-factor.

Table 1. Synthesis of ( $p) p p G p p$ in E. coli and M. xanthus cell extracts

\begin{tabular}{|c|c|c|c|c|c|c|c|c|c|c|c|c|}
\hline & \multicolumn{4}{|c|}{ E. coli extract } & \multicolumn{4}{|c|}{$M$. xanthus extract } & \multicolumn{4}{|c|}{ No cell extract added } \\
\hline & \multicolumn{2}{|c|}{$\begin{array}{c}\text { E. coli } \\
\text { ribosomes }\end{array}$} & \multicolumn{2}{|c|}{$\begin{array}{c}\text { M. xanthus } \\
\text { ribosomes }\end{array}$} & \multicolumn{2}{|c|}{$\begin{array}{c}\text { E. coli } \\
\text { ribosomes }\end{array}$} & \multicolumn{2}{|c|}{$\begin{array}{l}\text { M. xanthus } \\
\text { ribosomes }\end{array}$} & \multicolumn{2}{|c|}{$\begin{array}{c}\text { E. coli } \\
\text { ribosomes }\end{array}$} & \multicolumn{2}{|c|}{$\begin{array}{c}\text { M. xanthus } \\
\text { ribosomes }\end{array}$} \\
\hline & - & + & - & + & - & + & - & + & - & + & - & + \\
\hline Activity $^{a}$ & 2 & 1358 & 2 & 1285 & 2 & 178 & 3 & 132 & $<1$ & 2 & $<1$ & 5 \\
\hline
\end{tabular}

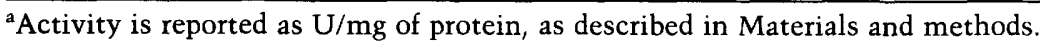




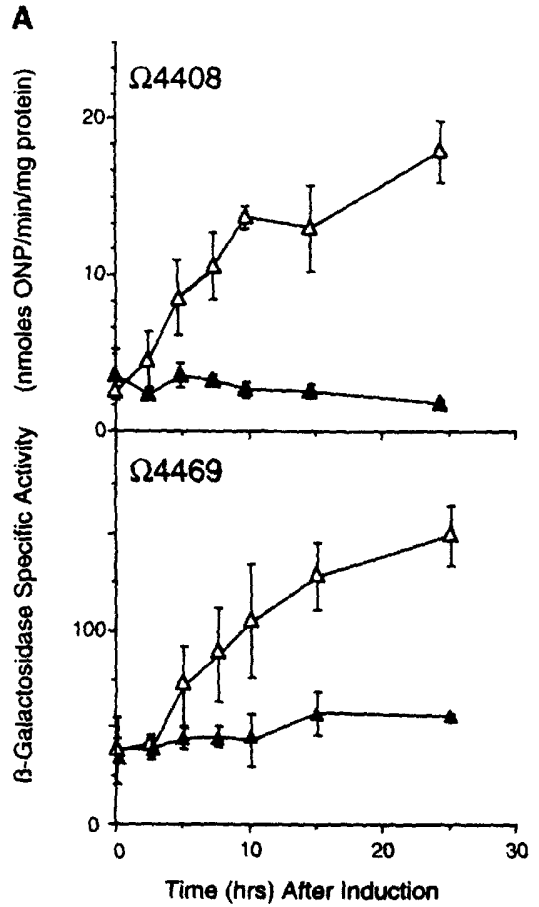

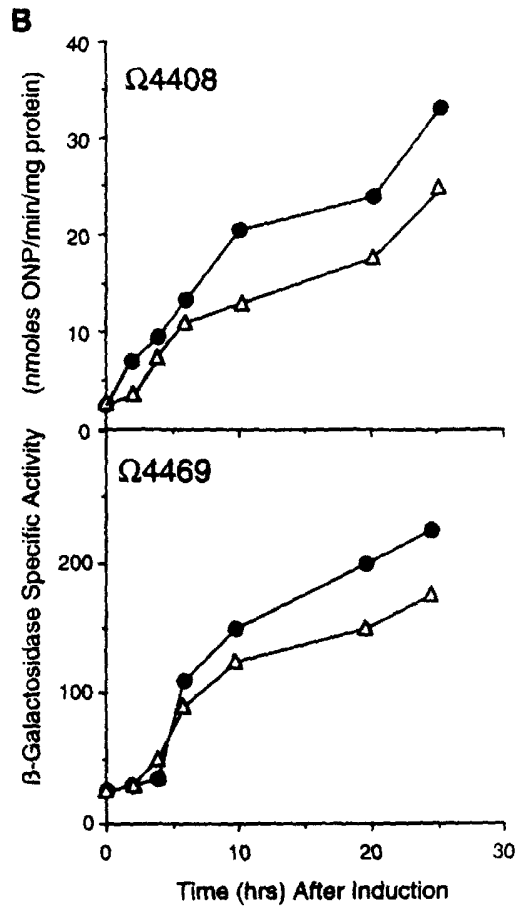

Figure 3. Expression of Tn5lac fusions $\Omega 4408$ and $\Omega 4469$ induced by light and starvation. $(A) \beta$-Galactosidase specific activity in DK101 pMS134 $(\Delta)$ and DK101 pMS133 (A) strains carrying Tn5lac fusions $\Omega 4408$ or $\Omega 4469$ in response to light induction in the presence of nutrients. Each time point represents the average of at least three independent experiments. $(B)$ Comparison of the induction profiles of strains DK101 pMS134 containing Tn5lac fusions $\Omega 4408$ or $\Omega 4469$ following starvation $(-$ or light induction $\{\Delta\rangle$.
Isogenic $M$. xanthus asg $B 480$ strains carrying the $\Omega 4521$ fusion and either pMS134 or pMS133 were assayed for $\beta$-galactosidase expression after light induction in the presence of nutrients. After light exposure, no increase in $\Omega 4521$ expression was observed (Fig. 4A) in either plasmid-bearing strain. Thus, expression of the $\Omega 4521$ fusion requires A-factor even when that expression is attributable to elevation of $(p) p p G p p$ without starvation.

Although the three- to fivefold increase in $\beta$-galactosidase from $\Omega 4521$ following expression of $E$. coli relA was substantial, the maximum expression appeared to be limited to $20 \%-30 \%$ of that observed from wild-type cells after starvation (Fig. 4B). Why should the proportionate activation by light of the $\Omega 4521$ fusion have been lower than the $70 \%$ activation of the $\Omega 4408$ and $\Omega 4469$ fusions, which are expressed at approximately the same time in the developmental program (cf. Fig. 3 and Fig. 4)? A-factor consists of a set of amino acids released by starving cells that are used at low concentration to assess the cell density (Kuspa et al. 1992b). Possibly relevant to the question posed above is the observation that amounts of amino acids higher than the signaling range and sufficient to support net protein synthesis and growth actually inhibit expression of the $\Omega 4521$ fusion and cause development to arrest (Kuspa et al. 1992a). The presence of a complete nutrient medium in the light induction protocol brings the level of amino acids well above their signaling range, and this offers one possible explanation for the relatively low level of $\beta$-galactosidase expression from the $\Omega 4521$ fusion in the presence of light and nutrients. The nutritionally complete minimal medium, A1 (Bretscher and Kaiser 1978), was employed in
A

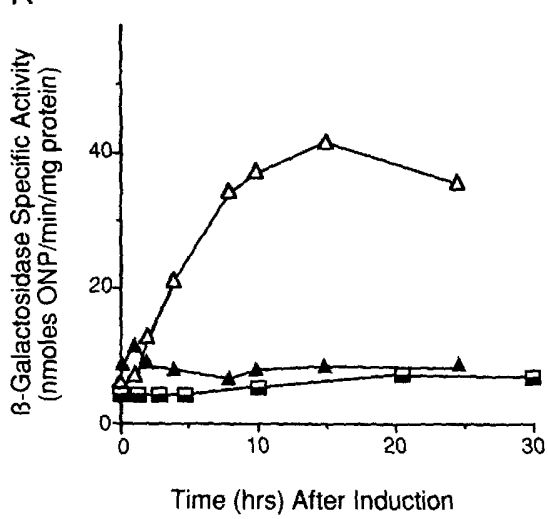

B

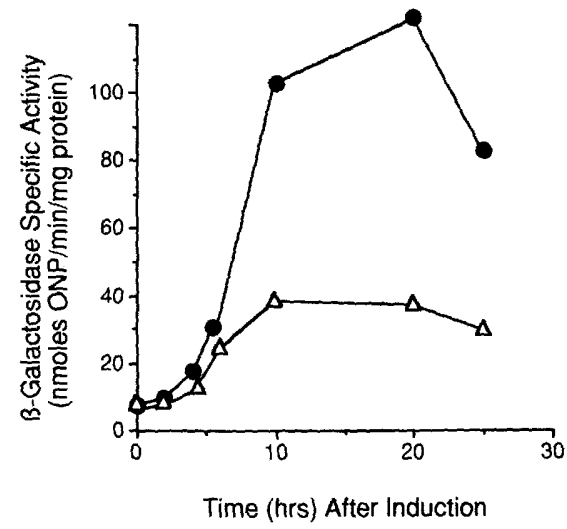

Figure 4. Expression of Tn5lac fusion $\Omega 4521$ induced by light and starvation. $(A)$ $\beta$-Galactosidase specific activity in DK101

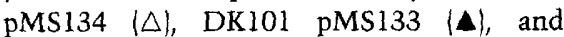
DK101 asgB480 pMS134 (ㅁ), and pMS133 (a) strains carrying Tn5lac fusions $\Omega 4521$ were measured in response to light induction in the presence of nutrients. $\beta$-Galactosidase expression was virtually identical for DK101 asgB480 carrying either plasmid, and for simplicity these data are represented as a single line. Each time point represents the average of at least three independent $\mathrm{ex}$ periments. $\langle B\rangle$ Comparison of the induction profiles of strains DK101 pMS134 containing Tn5lac fusion $\Omega 4455$ during starvation $(\mathrm{)})$ or light induction $(\Delta)$. 
the present studies of light-induced development. This medium contains three of the six most active A-factor amino acids and an amino acid concentration of $\sim 9 \mathrm{~mm}$, whereas the signaling range for amino acids is between $10 \mu \mathrm{M}$ and $1 \mathrm{~mm}$ (Kuspa et al. 1992b). These amino acids are either required for growth in minimal medium (Leu and Ile) or greatly enhance the growth rate (Phe). However, to demonstrate (p)ppGpp-induced development without starvation, a complete medium must be employed. In theory, then, the weak induction of $\Omega 4521$ by ppGpp could be rationalized by the growth levels of amino acids provided in Al medium and their inhibiting effect on A-signaling. This rationalization could explain why the A-factor-dependent fusion $\Omega 4521$ was affected but the A-factor-independent fusions $\Omega 4408$ and $\Omega 4469$ were not.

To challenge this explanation, and with the new insight gained from the experiments described above that a higher than signaling level of A-factor amino acids did not inhibit the expression of A-factor-independent fusions, we postulated that the A-factor amino acids were sensed by the A-signal transduction pathway, even when they exceeded the signaling range. This line of thought led to the construction of mutant strains of $M$. xanthus, containing sas $A 1$ and $a s g B 480$ mutations, that no longer required A-factor for the expression of the $\Omega 4521$ fusion (Kaplan et al. 1991). In effect, the expression of the $\Omega 4521$ fusion in sasA1 asgB480 strains, like the $\Omega 4408$ and $\Omega 4469$ fusion strains, depends on starvation but not on A-factor. Accordingly, pMS134 (containing E. coli relA) or pMS133 (identical to pMS134 but lacking $E$. coli relA) were introduced into an $M$. xanthus sas $A 1$ as $B B 40$ strain, and expression of $\beta$-galactosidase from the $\Omega 4521$ fusion was measured. Now, after exposure to light, expression from the $\Omega 4521$ fusion showed $>700$ units of $\beta$-galactosidase specific activity by $30 \mathrm{hr}$ in the strains carrying E. coli relA, which is $\sim 60 \%$ of the level observed by starvation induction (Fig. 5). Control strains without light-inducible $E$. coli relA were unable to activate expression from the $\Omega 4521$ fusion (Fig. $5 \mathrm{~A}$ ). Though expression of the $\Omega 4521$ fusion was delayed in the lightinduced cells relative to the starvation-induced cells by $1-2 \mathrm{hr}$, the rate of $\beta$-galactosidase expression rose to $\sim 40 \%$ of the rate observed following starvation /cf. the slopes in Fig. 5B).

\section{Effect of GTP levels on fruiting body development}

In $B$. subtilis, despite a stringent response strong enough to stop DNA replication after amino acid starvation, a decrease in the GTP pool is apparently sufficient to initiate endospore formation (Lopez et al. 1979; Ochi et al. 1982; Levine et al. 1991). In M. xanthus, even though (p)ppGpp is synthesized from GTP, the GTP levels decrease only slightly when fruiting body formation is induced by starvation (Manoil and Kaiser 1980a; Manoil 1982). As shown above in Figure 2C, no decrease in GTP levels was detected after light induction of $\mathrm{relA}$ and (p)ppGpp synthesis. Nevertheless, there seemed to remain a possibility that a small decrease (below the level of detection) of intracellular GTP concentration accompanies (p)ppGpp synthesis and that this decrease in the GTP level, rather than the elevation of (p)ppGpp, is the primary inducer of development. To address this possibility, two antibiotics, mycophenolic acid, which inhibits IMP dehydrogenase and thus decreases GTP synthesis, and decoyinine, which inhibits GMP synthetase, were examined for their ability to initiate development in $M$. xanthus. Either antibiotic induces endospore formation in B. subtilis (Freese et al. 1979; Lopez et al. 19791.

M. xanthus strain DK101 was exposed to either my-
Figure 5. Expression of Tn5lac fusions $\Omega 4521$ in sasA1 asgB480 mutants induced by light and starvation. (A) $\beta$-Galactosidase specific activity in DK101 sas $A 1$ asgB480 pMS134 $(\triangle)$ and DK101 sas $A 1$ asgB480 pMS133 (A) strains carrying Tn5lac fusions $\Omega 4521$ were assayed for $\beta$-Galactosidase expression in response to light induction in the presence of nutrients as described in Materials and methods. Each time point represents the average of at least two independent experiments. (B) Comparison of the induction of $\beta$-galactosidase expression patterns of strains DK101 sasA1 asgB480 pMS134 containing Tn5lac fusion $\Omega 4521$ during starvation $(O)$ or after light induction $(\Delta)$.
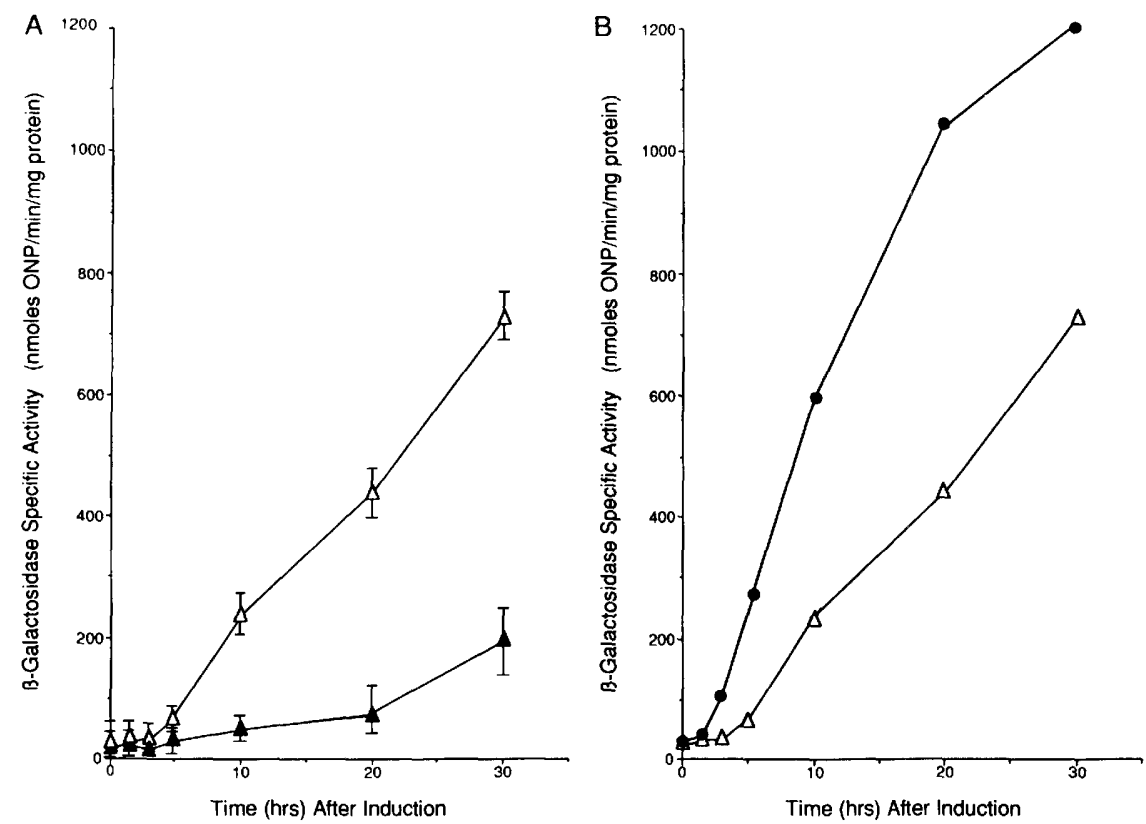
cophenolic acid or decoyinine over 10-fold ranges in their concentrations; growth, ATP, GTP, and ppGpp levels were then examined. Within $2 \mathrm{hr}$ of antibiotic addition the intracellular GTP concentration decreased $65 \%-80 \%$ after exposure to $160 \mu \mathrm{g} / \mathrm{ml}$ of mycophenolic acid (Fig. 6A), or to $500 \mu \mathrm{g} / \mathrm{ml}$ of decoyinine (Fig. 6B). Such decreases in intracellular GTP concentrations had been found sufficient to induce endospore formation in B. subtilis (Lopez et al. 1981; Ochi et al. 1982).

Whether such a decrease in the GTP level was capable of initiating $M$. xanthus fruiting body development was assessed by measuring early developmental gene expression and myxospore formation. The same three early reporter fusions employed previously $(\Omega 4408, \Omega 4469$, and $\Omega 4521$ ), which are expressed in response to (p/ppGpp elevation, were not significantly expressed after antibiotic addition (Fig. 7). Nor was either mycophenolic acid or decoyinine able to induce sporulation (or aggregation). Starvation-induced DK101 cells produced $1 \times 10^{7}$ to $2 \times 10^{7}$ spores $/ \mathrm{ml}$. DK101 cells in the presence of 160 $\mu \mathrm{g} / \mathrm{ml}$ of mycophenolic acid or $500 \mu \mathrm{g} / \mathrm{ml}$ of decoyinine in Al medium produced no more than $20-50$ spores $/ \mathrm{ml}$. This level was similar to that of the controls to which no antibiotic had been added (10-30 spores $/ \mathrm{ml}$ ).

To ensure that these antibiotics were not inducing and simultaneously interfering with development through effects on guanine nucleotide metabolism, the antibiotics were added to a culture of starving $M$. xanthus cells. Neither antibiotic was found to inhibit fruiting body formation or sporulation at concentrations as high as 160 $\mu \mathrm{g} / \mathrm{ml}$ of mycophenolic acid or $500 \mu \mathrm{g} / \mathrm{ml}$ of decoyinine, respectively. Apparently, residual GTP synthesis was sufficient to support necessary protein synthesis and (p)ppGpp synthesis. Higher antibiotic concentrations 1>320 $\mu \mathrm{g} / \mathrm{ml}$ of mycophenolic acid or $>1 \mathrm{mg} / \mathrm{ml}$ of decoyinine) did inhibit aggregation and sporulation. At

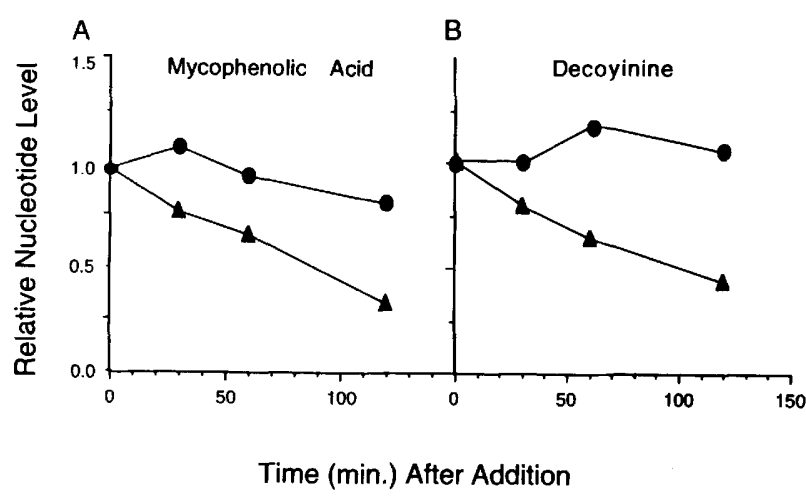

Figure 6. GTP levels in $M$. xanthus exposed to mycophenolic acid or decoyinine. Amounts of $160 \mu \mathrm{g} / \mathrm{ml}$ of mycophenolic acid $(A)$ or $500 \mu \mathrm{g} / \mathrm{ml}$ of decoyinine $(B)$ were added to $M$. xanthus, and GTP $(\mathbf{\Delta})$ and ppGpp $(\mathbf{O})$ were extracted and separated by TLC. Cells were grown in Al medium and labeled, and nucleotides were extracted and quantitated as described in Materials and methods. At time zero, either mycophenolic acid or decoyinine were added to exponentially growing cultures. Samples were removed at the times indicated.

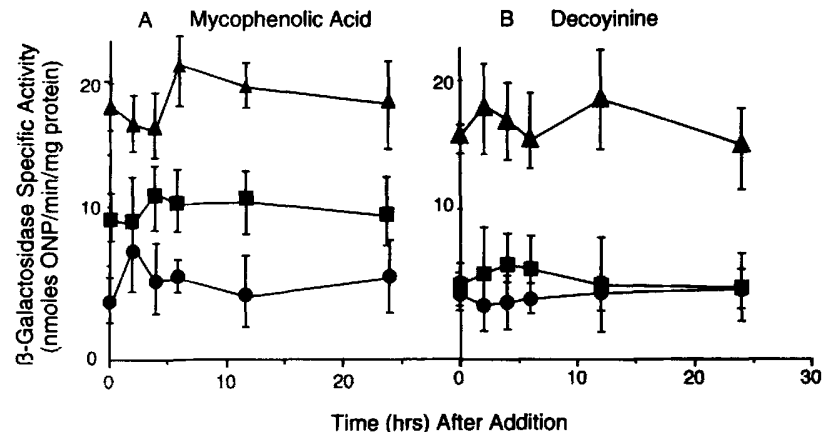

Figure 7. Inhibition of GTP synthesis by mycophenolic acid or decoyinine and developmental gene expression. Developmental $\beta$-galactosidase expression from DK101 strains carrying Tn5lac fusions $\Omega 4408$ (O), $\Omega 4521$ ( $\mathbf{\square}$ ), or $\Omega 4469$ ( $\mathbf{\Delta}$ ) was performed as described in Materials and methods. Cells were spotted onto Al agarose plates containing either $160 \mu \mathrm{g} / \mathrm{ml}$ of mycophenolic acid $(A)$, or $500 \mu \mathrm{g} / \mathrm{ml}$ of decoyinine $(B)$.

these high concentrations, however, ATP levels as well as GTP levels were severely depressed (data not shown).

\section{Discussion}

Experiments reported here argue that the production of (p)ppGpp is sufficient to initiate the developmental program in $M$. xanthus. In the laboratory and presumably in nature, fruiting bodies develop in response to starvation. When bacteriolytic myxobacteria like $M$. xanthus are cultivated on buffered casein hydrolysate, and then transferred to a buffered salts medium (TPM), there is an abrupt starvation for amino acids, carbon, nitrogen, sulfur, and energy. Under such conditions $M$. xanthus, like most Gram-negative bacteria, gives a stringent response, elevating (p)ppGpp and arresting synthesis of rRNA (Manoil 1982; M. Singer, unpubl.). M. xanthus also elevates cAMP, presumably as a consequence of carbon starvation (Yajko and Zusman 1978). Neither of these responses is exceptional, and other stress responses may be mounted as well under such conditions (Nelson and Killeen 1986). Rather, the issue is how starvation initiates the program of fruiting body development.

Fruiting body development is biologically costly, as often only $1 \%$ of the initial population of cells survive as spores within fruiting bodies (Wireman and Dworkin 1977; O'Connor and Zusman 1988). Moreover, M. xanthus has at least one other alternative: to grow slowly at a rate compatible with its level of stored nutrients. This alternative becomes problematic when the starvation is prolonged and all the cells eventually die, because only under nonphysiologic conditions do individual $M$. xanthus cells form myxospores (Dworkin and Gibson 1964).

The issue confronted by this report is whether an elevation of (p)ppGpp, without nutrient starvation can initiate the developmental program. For this purpose $E$. coli relA, encoding the pppGpp synthetase I enzyme, was introduced into $M$. xanthus, where it was placed under control of the blue light-inducible carQRS promoter. 
Following exposure to light, the E. coli RelA protein accumulated and the intracellular (p)ppGpp concentration rose steadily to five- to eightfold within $4 \mathrm{hr}$ (Fig. 2C). Despite the presence of nutrients capable of supporting cell growth, growth ceased and three transcriptional lacZ fusion reporters, $\Omega 4408, \Omega 4469$, and $\Omega 4521$, were expressed. Each of these reporters is fused to a different promoter that becomes active at its characteristic time within the first four hours of fruiting body development (Kroos et al. 1986). This discussion will focus on two questions: (1) Are the observed changes in gene expression due to (p)ppGpp; and (2) To what extent has the program of fruiting body development been initiated?

To address the question of specificity for (p/ppGpp, each experiment contrasted the level of gene expression observed with the relA-encoding plasmid with the same plasmid without relA, and with the level prior to light exposure. In every case, both the relA-encoding plasmid and exposure to light were necessary. The observed increases in gene expression followed light exposure within an interval of time appropriate for the carQRS circuit response (Hodgson 1993). A clear limitation of these experiments is that the (hypothetical) level of (p)ppGpp necessary for expression of the reporters is unspecified; all that can be argued at this time is that some elevation of $/ p / p p G p p$ is required and sufficient to elicit this response.

To address the question of specificity further, several alternative explanations of the data were tested. One possible alternative was that expression of the E. coli RelA protein, which is not an $M$. xanthus protein, stressed the protein synthetic capacity of $M$. xanthus and that this stress could both initiate the developmental program and induce (p)ppGpp synthesis. This alternative was examined in a control experiment in which a different unrelated protein, the E. coli $\beta$-galactosidase (lacZ) was placed under control of the carQRS promoter in $M$. $x$ anthus and induced by exposure to light. This led to a 20 -fold increase in $\beta$-galactosidase activity which became $1 \%-5 \%$ of the total cell protein. This accumulation of $\beta$-galactosidase led at most to a $30 \%$ increase in the (p)ppGpp level. In contrast, the light-induced expression of RelA, resulting in an accumulation of $<1 \%$ of the total cell protein, led to a 500 to $800 \%$ increase in (p)ppGpp, over the same time interval. In the same vein, we note that expression of other unrelated proteins encoded by the plasmids, pMS131 and pMS133 also failed to induce significant accumulation of (p)ppGpp (Fig. 2). The basal level of $\mathrm{ppGpp}$ in the presence or absence of plasmid is $\sim 1.5 \times 10^{-13}$ mole/Klett unit. The NptII and tetracycline resistance proteins, which are expressed to levels sufficient for resistance to their respective antibiotics, are also unrelated proteins. These results imply that the accumulation of $(\mathrm{p} / \mathrm{ppGpp}$ is not a response to the expression of any unrelated protein but is specific to expression of the E. coli RelA protein.

Another potential alternative is that development is not induced by the elevation of (p)ppGpp but by depression of GTP, its precursor, as is the case of $B$. subtilis (Lopez et al. 1979). Two pieces of evidence argue against this alternative. First, when developmental gene expression was induced by exposure to light, virtually no decrease in GTP was observed (Fig. 2C). Second, two antibiotics that depress GTP synthesis and are capable of initiating sporulation in B. subtilis (Lopez et al. 1979) were tested in $M$. xanthus. Neither decoyinine nor mycophenolic acid was able to induce $M$. xanthus fruiting body development or sporulation, nor to activate developmental gene expression (Fig. 7).

The second question to be addressed is the extent to which the data demonstrate that the developmental program has been initiated. A fundamental limitation to the experiments reported here is that they do not demonstrate that development of fruiting bodies occurs in response to an elevation of (p)ppGpp. Instead, they show an increased expression of a set of $l a c Z$ reporter fusions. The failure to form fruiting bodies is attributable to a technical limitation in the use of the light-inducible carQRS promoter, which is the only regulatable promoter that is currently available in $M$. xanthus. The technical limitation is that the amount of light necessary to activate carQRS also blocks fruiting body development some time after 6-10 hr (Li et al. 1992; Gill and Shimkets 1993). Therefore, it has been necessary to utilize $l a c Z$ reporter fusions that are expressed prior to $6 \mathrm{hr}$ of development. Several arguments justify the use of these reporter fusions as indicators for the activation of the developmental program.

First, the reporters chosen, $\Omega 4408, \Omega 4469$, and $\Omega 4521$, are development specific in that their expression rises above a low level during growth to higher levels after development has been induced by starvation. The increases range from 15 -fold for $\Omega 4408$, 10-fold for $\Omega 4469$, and 10 -fold for $\Omega 4521$ (see Figs. $3 \mathrm{~B}$ and $4 \mathrm{~B}$ ). In addition the $\Omega 4408$ insertion inactivates a gene that clearly is specific and essential for the developmental program. An insertion of Tn 5 at $\Omega 4408$ causes development to arrest just prior to the mounded aggregate stage at $\sim 6-8 \mathrm{hr}$ after starvation, and the strain grows normally (Kroos et al. 1990). Expression of $\Omega 4408$ is intimately associated with development. None of these three fusions are expressed when fruiting body development is bypassed and sporulation is induced by $0.5 \mathrm{M}$ glycerol (Kroos 1986).

Second, expression from each of these fusions begins at a characteristic time: $\Omega 4408$ within $30 \mathrm{~min}$ post-starvation, $\Omega 4469$ at $3-5 \mathrm{hr}$, and $\Omega 4521$ at $2 \mathrm{hr}$. Although the initiation times are later following exposure to light than after starvation, the same time order of expression is observed: first $\Omega 4408$, then $\Omega 4521$, and then $\Omega 4469$.

Third, expression of these reporters had the same dependence on intercellular signals after exposure to light: $\Omega 4408$ and $\Omega 4469$ are independent of A-factor whereas $\Omega 4521$, though expressed earlier than $\Omega 4469$ is dependent on A-factor, a signal of cell density. Light-induced expression of $\Omega 4521$ by ectopic $E$. coli RelA production still requires A-factor production, or a specific bypass of the A-signaling pathway. The A-factor requirement for $\Omega 4521$ expression can be relieved by the sas $A$ suppressor following exposure to light, just as it is following starvation (see Fig. 5B). Recently I. Keseler has mapped the 
transcription start site for $\Omega 4521$ and has identified its promoter as a member of the sigma-54 family (Keseler and Kaiser 1995). In addition Gulati et al. (1995) have shown that about 120 base pairs upstream of their promoter were sufficient for starvation and A-factor-dependent expression of $\Omega 4521$. Because sigma-54 promoters always have an upstream activator protein, such promoters offer one way to integrate two or more signals.

\section{A two-level starvation recognition model for induction of fruiting body development in $\mathrm{M}$. xanthus}

In their developmental phase, 100,000 cells aggregate to construct a multicellular fruiting body. This construction starts before the cells have entirely lost their capacity to synthesize proteins, because at least 30 new proteins are made as fruiting bodies form (Inouye et al. 1979|. Moreover, only a fraction of the starting cells will survive by becoming spores; the majority $(90 \%-99 \%)$ of cells die (Wireman and Dworkin 1977), unless special osmotic support is provided $\left(\mathrm{O}^{\prime}\right.$ Connor and Zusman 1988). Because fruiting body formation is thus initiated in anticipation of total starvation and because fruiting body development involves the death of the majority of the population, evolutionary selection would have favored an accurate assessment of nutritional status, perhaps more accurate than any individual cell can achieve. Higher accuracy could be found, however, if the cells monitored the nutritional status of the entire population via the total level of A-factor in the medium. By responding to two starvation stimuli, a cellular signal, which we propose to be (p/ppGpp, and a population signal represented by the level of A-factor, the needed accuracy may be achieved.

The initiation of development by starvation can be explained by the two-level model diagrammed in Figure 8. The first level is an intracellular signal of starvation that allows each cell to evaluate its own nutritional status. The evidence provided here says that elevation of (p)ppGpp signals starvation to the cell. Previous experiments have shown that (p/ppGpp is necessary for development (Manoil and Kaiser 1980b); experiments reported herein argue that elevation of (p)ppGpp can replace starvation for the induction of the early stages of development. $M$. xanthus exhibits a classic stringent response to amino acid starvation at the level of stable RNA synthesis and, therefore, must have the requisite enzymes of (p)ppGpp metabolism (Manoil and Kaiser 1980a; M. Singer, unpubl.). As (p)ppGpp is synthesized by ribosomes that have stalled because of the lack of an aminoacylated tRNA, it provides an evaluation of nutritional status in terms of the cell's global protein synthetic capacity (Cashel and Rudd 1987). Utilizing (p)ppGpp and the stringent response for control of fruiting body development would seem to be appropriate for several reasons. First, $M$. xanthus uses amino acids as its major sources of carbon, nitrogen, and energy. The stringent response evaluates the availability of all 20 amino acids in proper proportion for protein synthesis. Second,

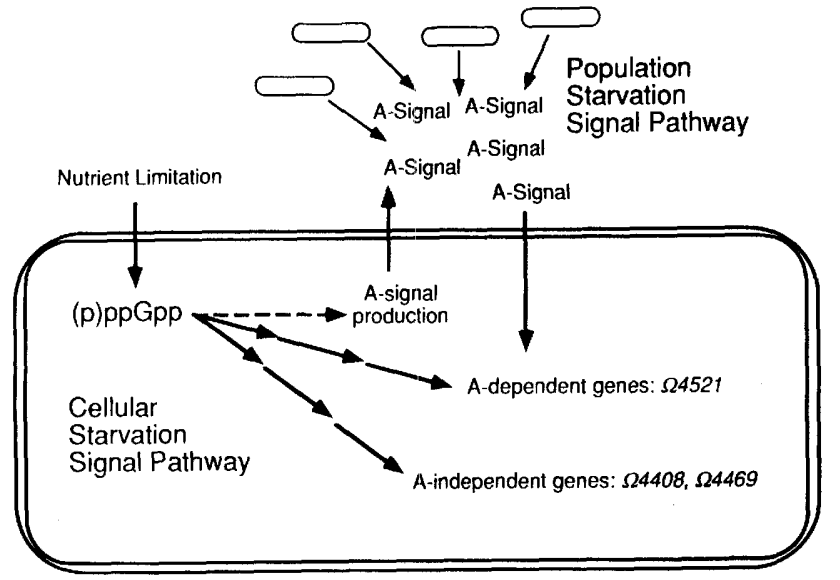

Figure 8. A model for two-level starvation recognition in $M$. xanthus. As nutrient levels decrease and the protein synthetic capacity of the cell decreases, the (p)ppGpp levels will increase. When the (p)ppGpp levels have risen to some point, starvationinduced genes receive the $(\mathrm{p} / \mathrm{ppGpp}$ signal as indicated by the solid arrows. These genes include the A-signal-independent genes such as $\Omega 4408$ and $\Omega 4469$, and the A-signal-dependent gene $\Omega 4521$, which also requires A-signal. We suggest that the rise in (p)ppGpp activates the production of A-signal, directly or indirectly, as shown by the broken arrow. Outside the cell, A-signal begins to accumulate as more and more cells, encountering starvation, release the A-signal. At a certain concentration of extracellular A-signal, A-signal-dependent genes are activated. These genes, such as $\Omega 4521$ have already received the starvation signal and are waiting for A-signal to become activated.

(p)ppGpp accumulates rapidly in response to amino acid starvation (Fig. 1). Within $30 \mathrm{~min}$, there is a 10-fold rise in the (p/ppGpp level, and cells would thus be able to rapidly sense and respond to nutrient deprivation. Because (p)ppGpp is rapidly degraded, cells could abort an initial response to starvation if an alternative source of food is located, the amino-acylated tRNA level restored, and the (p)ppGpp level returns to normal.

During this early phase of uniquely cellular response, cells would activate early developmentally regulated genes, such as those represented by the $\Omega 4408$ and $\Omega 4469$ reporters. The current data are insufficient to say whether activation by (p)ppGpp is direct or indirect. In addition, we suggest that a sufficient (p)ppGpp accumulation would cause individual cells to begin to produce A-factor, thereby signaling the rest of the population that they have detected a serious nutrient limitation and are preparing for fruiting body development, as opposed to stationary growth. As more and more cells opt for fruiting body development, the level of A-factor would rise in the extracellular environment.

In a second (populational) level of starvation detection, the cells would respond to A-factor. A-factor begins to accumulate in the medium about an hour after a culture is starved (Kuspa et al. 1986) and rises to a steady state between 2 and $4 \mathrm{hr}$ after starvation (Kuspa et al. 1992b). A-factor behaves as a cell density signal because the 
amount of A-factor produced is proportional to the cell density and because there is a threshold concentration for the response to A-factor (Kuspa et al. 1992b). If A-factor is released by cells that have evaluated starvation as serious, its level of accumulation in the medium would reflect the assessments of all the cells in the population as to the nature of the nutrient limitation. Thus, we suggest that the level of A-factor summarizes the decisions of many cells within a population that the level of starvation justifies the biological cost of fruiting body development. In this sense, it would be analogous to the accumulation of autoinducer that controls the expression of the lux genes in several Vibrio species in response to cell density (Nealson et al. 1970; Eberhard 1972; Kaplan and Greenberg 1985; Bassler et al. 1994), and termed "quorum-sensing" (Fuqua et al. 1994). A two-signal mechanism would allow cells to recognize starvation individually, and then if conditions warrant and the number of cells is adequate, to organize the multicellular effort required to build a fruiting body.

\section{Materials and methods}

Strains, phages, plasmids, and genetic manipulations

The starting strain for these studies was the wild-type strain DK101, a developmentally competent strain that contains an sglA1 mutation resulting in a social motility defect (Hodgkin and Kaiser 1979). The transducing myxophages Mx4 ts18 ts27 hrm (Campos et al. 1978) and Mx8 clp2 (Martin et al. 1978) have been described previously and were used to transduce the Tn5lac fusions $\Omega 4521, \Omega 4408$, and $\Omega 4469$ from strains DK4521, DK4300, and DK4469, respectively, into DK101. Strains DK4324, asgB480 $\Omega 4521$ and DK6601, asgB480 sasA1 $\Omega 4521$ have been described previously (Kaplan et al. 1991).

Plasmids pMS132, pMS131, pMS133, and pMS134 were constructed as follows. The carQRS promoter containing a 415-bp SacI-BgIII fragment from pDAH328 (Hodgson 1993) was inserted into the Sacl and BglII sites of pICl9H (Marsh et al. 1984) and renamed pMS127. The 2.3-kb E. coli relA-encoding EcoRIBamHI fragment from pALS10 (a gift from M. Cashel, National Institutes of Health, Bethesda, MD) was inserted into corresponding sites of pMS127, yielding pMS129. The resulting 2.8 $\mathrm{kb}$ HindIII fragment, which now contains the $E$. coli relA gene behind the $M$. xanthus carQRS promoter, was inserted into the HindIII site of pPLH343 (Kalman et al. 1994), giving rise to pMS132. This plasmid contains the kanamycin resistance gene and the Mx8 phage attachment site, which allows for site-specific recombination within the $M$. xanthus genome. A tetracycline-resistant derivative, pMS134, was constructed by inserting a 1.4-kb XhoI-SmaI tetracycline cassette into the XhoI-SspI sites of pMS132, thereby inactivating the resident kanamycin resistance gene. Plasmids pMS131 and pMS133 are identical to pMS 132 and pMS134, respectively, except that they lack the $E$. coli relA gene. These plasmids were introduced into $M$. xanthus strain DK101 and DK101 derivatives carrying various Tn5lac reporter fusions by electroporation as described previously (Kalman et al. 1994). Plasmid pDAH217 was a gift from D. Hodgson (1993).

\section{Growth and developmental conditions}

Cells were grown in either CTT [ $1 \%$ casitone (Difco Laboratories), $10 \mathrm{mM}$ Tris-hydrochloride $(\mathrm{pH} 7.6), 1 \mathrm{mM} \mathrm{KHPO}{ }_{4}(\mathrm{pH} 7.6)$,
$8 \mathrm{mM} \mathrm{MgSO}_{4}$ ) liquid or Al liquid (Bretscher and Kaiser 1978) at $33^{\circ} \mathrm{C}$ with vigorous aeration. For solid support, $1.5 \%$ agar (CTT) or agarose (A1) was added as described previously (Bretscher and Kaiser 1978). When indicated, medium was supplemented with $12 \mu \mathrm{g} / \mathrm{ml}$ of oxytetracycline, $40 \mu \mathrm{g} / \mathrm{ml}$ of kanamycin, mycophenolic acid (Sigma, St. Louis, MO), or decoyinine (Upjohn, Kalamazoo, MI), as indicated in text. Cell growth in liquid cultures was monitored using a Klett-Summerson photoelectric colorimeter (model 800-3) equipped with a red filter.

Initiation of development by starvation was performed as described previously (Kroos et al. 1986). In summary, exponentially growing cells were concentrated by centrifugation $16000 \mathrm{~g}$ for $10 \mathrm{~min}$ at $10^{\circ} \mathrm{C}$, washed once with TPM buffer $[10 \mathrm{mM}$ Tris-hydrochloride (pH 7.5), $1 \mathrm{mM} \mathrm{KPO}_{4}$ (pH 7.6), $8 \mathrm{~mm} \mathrm{MgSO}_{4}$ ), and then resuspended in the same buffer to a final cell concentration of $5 \times 10^{9}$ cells $/ \mathrm{ml}$. Twenty-microliter samples were then spotted onto TPM agar plates. For developmental $\beta$-galactosidase assays, five spots were scraped and pooled for analysis at times indicated in the text. Preparation of samples for $\beta$-galactosidase assays was performed as described previously (Kroos et al. 1986). The rate of $\beta$-galactosidase expression was determined by calculating the slope of the activity curve and the coordinate where the slope extrapolated back onto the $x$ (time)axis was used to determine the time of initial expression, as described previously (Kroos et al. 1986).

\section{Light induction of $\mathrm{E}$. coli relA}

Induction of $E$. coli relA in $M$. xanthus strains grown in liquid medium was performed as follows. Cells were grown in CTT or Al liquid with vigorous shaking in the dark at $33^{\circ} \mathrm{C}$. At the indicated time, exponentially growing cells were exposed to light. Irradiance at the culture surface was $2.081 \times 10^{-3} \mathrm{~W} / \mathrm{cm}^{2}$, measured from 250 to $800 \mathrm{~nm}$ at l-nm intervals by an OL752 spectroradiometer, (Optronics Labs) provided by two F15T8-CW Sylvania cool white fluorescent bulbs at a distance of $10 \mathrm{~cm}$ from the culture surface. Samples were removed at various times after light induction to monitor the production of $E$. coli RelA protein and (p)ppGpp levels.

Induction of $E$. coli relA in $M$. xanthus strains growing on solid medium was performed as described for starvation-induced development with the following modifications. Cells were grown exponentially in $\mathrm{Al}$ medium in the dark and then harvested, washed, and resuspended in Al medium. Twentymicroliter samples were then spotted onto Al agarose plates and exposed to light as described above. $\beta$-Galactosidase assays were performed as described for starvation-induced development.

\section{Quantitation of guanosine nucleotides}

In vivo analysis of DK101 guanosine nucleotides was performed as described by Manoil and Kaiser (1980a). In summary, for steady-state labeling of $\left[{ }^{32} \mathrm{P} \mid\right.$ phosphate in $M$. xanthus, cells were labeled for $6 \mathrm{hr}$ with [ ${ }^{32} \mathrm{P}$ |orthophosphate (NEN, NEX-053, $8500-9120 \mathrm{Ci} / \mathrm{mmole}, 100 \mu \mathrm{Ci} / \mathrm{ml}$ ) in CTT or $12 \mathrm{hr}$ in Al liquid medium to equilibrate the intracellular phosphate pools. Manoil and Kaiser demonstrated previously that GTP and ppGpp pools equilibrate within 3-4 hr under these conditions (Manoil 1982). At a culture density of $2 \times 10^{8}$ to $3 \times 10^{8}$ cells $/ \mathrm{ml}$, cells were shifted to TPM starvation buffer or fresh A1 medium containing $100 \mu \mathrm{Ci} / \mathrm{ml}$ of $\left[{ }^{32} \mathrm{P}\right]$ orthophosphate. One-milliliter culture samples were removed prior to the shift (reference sample) and at various times after the shift as described in the text.

Studies examining the effect of mycophenolic acid and decoyinine on nucleotide levels, cultures were labeled with 
$\left[{ }^{32} \mathrm{P}\right]$ orthophosphate as described above, and at time 0 were then divided between the control, no addition, and the experimental, containing the antibiotics. Samples were removed at times indicated in the text and processed as described below.

Nucleotides were extracted and analyzed by thin-layer chromatography (TLC) as described previously (Manoil and Kaiser $1980 \mathrm{a}, \mathrm{b} \mid$. The amount of radioactivity in each nucleotide spot on the TLC plates was quantified on a PhosphorImager $400 \mathrm{~S}$ (Molecular Dynamics, Sunnyvale, CA) equipped with the ImageQuant v. 3.5 program (Molecular Dynamics, Sunnyvale, CA).

\section{Western analysis}

One-tenth milliliter samples were removed from the culture before and after light induction at the times indicated in Figure 2A. Samples were lysed in SDS sample buffer (Straus et al. 1987), and the proteins were resolved on $7.5 \%$ polyacrylamide gels. Transfer and blotting were performed as described previously (Straus et al. 1987) using anti-E. coli RelA antibody provided by G. Glaser (Hadassa Medical School, Jerusalem, Israel).

\section{In vitro assay for (p)ppGpp synthesis}

Partially purified E. coli (strain MG1655, a wild-type K12 strain) and $M$. xanthus (DK101) cell extracts were assayed for their ability to synthesize (p)ppGpp in vitro as described previously (Block and Haseltine 1975), with the following modifications. Reaction mixtures contained $42 \mathrm{~mm}$ Tris-acetate $(\mathrm{pH} 8), 1.4 \mathrm{~mm}$ dithiolthreitol, $12.8 \mathrm{~mm}$ magnesium acetate, $12 \mathrm{mM}$ potassium acetate, $50 \mathrm{~mm}$ ammonium chloride, $2 \mathrm{~mm}$ ATP, $0.2 \mathrm{~mm}$ GTP, $1 \mu \mathrm{Ci}$ of $\left[\alpha^{-32} \mathrm{P}\right] \mathrm{GTP}$ (NEN, NEG-006H, $3000 \mathrm{Ci} / \mathrm{mmole}, 10$ $\mathrm{mCi} / \mathrm{ml}), 4 \mu \mathrm{l}(120 \mu \mathrm{g})$ of ethanol-washed ribosomes (see below) either from $E$. coli or from $M$. xanthus as indicated, and $5 \mu$ l of the RelA-containing fraction from either $E$. coli or $M$. xanthus as indicated (see below). Reaction mixtures were incubated at $28^{\circ} \mathrm{C}$ for $15 \mathrm{~min}$ and then terminated by the addition of formic acid to a final concentration of $1 \mathrm{M}$. (p)ppGpp synthetase activity from the $M$. xanthus extracts was inactivated at temperatures above $30^{\circ} \mathrm{C}$; therefore, all measurements were made at $28^{\circ} \mathrm{C}$. To measure the synthesis of $(\mathrm{p}) \mathrm{ppGpp}, 10 \mu \mathrm{l}$ of the reaction mixture was separated by chromatography on thin layer polyethyleneimine (PEI) plates as described by Block and Haseltine (Block and Haseltine 1975) and the amount of radioactivity in each spot was quantitated by a PhosphorImager as described above. For these experiments 1 unit was defined as 1 pmole of (p)ppGpp formed per minute. It should be noted that this definition is different from that of Block and Haseltine (1975).

\section{Preparation of cell extracts}

Extracts of wild-type E. coli strain MGl655 and M. xanthus strain DK 101 were prepared as described by Block and Haseltine (1975), with minor modifications. For disruption, 40 grams of cell paste was passed through a French pressure cell at 3000 psi. The broken cells were subjected to centrifugation at $30,000 \mathrm{~g}$ for 30 min to sediment cell debris. The supernatant was spun down at $100,000 \mathrm{~g}$ for $4 \mathrm{hr}$ and the pellet fraction (P-100) saved. For $E$. coli this $\mathrm{P}-100$ fraction was washed by suspension in buffer $\mathrm{C}$ $0.5 \mathrm{M} \mathrm{NH}_{4} \mathrm{Cl}, 10 \mathrm{~mm}$ Tris at $\mathrm{pH} 8,1 \mathrm{~mm}$ dithiolthreitol, $14 \mathrm{~mm}$ magnesium acetate, $60 \mathrm{mM}$ potassium acetate, $5 \%$ glycerol, and $2 \mathrm{mM}$ EDTA) followed by resedimentation. For $M$. xanthus extracts, $1 \mathrm{M}$ ammonium chloride was required to efficiently remove RelA activity from the $\mathrm{P}-100$ fraction, and buffer $\mathrm{C}$ was so modified. The buffer $\mathrm{C} / \mathrm{NH}_{4} \mathrm{Cl}$-washed $\mathrm{P}-100$ pellet was then used as the source of ribosomes described below. The buffer
$\mathrm{C} / \mathrm{NH}_{4} \mathrm{Cl}$ elute (either $0.5 \mathrm{M} \mathrm{NH}_{4} \mathrm{Cl}$ for $E$. coli or $1 \mathrm{M} \mathrm{NH}_{4} \mathrm{Cl}$ for $M$. xanthus) was then subjected to a $0 \%-35 \%$ saturated ammonium sulfate precipitation step, and the resulting precipitate dialyzed against $0.5 \mathrm{M} \mathrm{NH}_{4} \mathrm{Cl} /$ buffer $\mathrm{C}\left(0.5 \mathrm{M} \mathrm{NH}_{4} \mathrm{Cl}\right.$ was used for both $M$. xanthus and $E$. coli) to remove the ammonium sulfate. This fraction was the source of RelA for the in vitro synthesis of $(p / p p G p p$ reactions described above and is equivalent to the step 2 fraction of Block and Haseltine (1975).

Ethanol-washed ribosomes for both $E$. coli and $M$. xanthus were prepared as follows. The $\mathrm{NH}_{4} \mathrm{Cl}$-washed $\mathrm{P}-100$ pellet was washed five times by resuspending the $\mathrm{P}-100$ in buffer $\mathrm{C}$ adjusted to $1 \mathrm{M} \mathrm{NH}_{4} \mathrm{Cl}$. These washed ribosomes were then precipitated with $50 \%$ ethanol at $0^{\circ} \mathrm{C}$. This was repeated, and the ribosomes were finally resuspended in buffer B $(10 \mathrm{~mm}$ Tris at $\mathrm{pH} 8,1 \mathrm{~mm}$ dithiolthreitol, $14 \mathrm{~mm}$ magnesium acetate, $60 \mathrm{~mm}$ potassium acetate) at a concentration of $30 \mathrm{mg} / \mathrm{ml}$

\section{Acknowledgments}

We are grateful to $\mathrm{M}$. Cashel for providing plasmid pALS10 and D. Hodgson for providing plasmids pDAH328 and pDAH217; G. Glaser for providing anti-E. coli RelA antibody, and the Upiohn company for the gift of decoyinine. We also thank Hanya Chrispeels for her technical assistance in determining light measurements and A. Grossman, H. Kaplan, G. Marczynski, L. Plamann, C. Stephens, and members of the Kaiser laboratory for helpful discussions and for critical reading of the manuscript. This work was supported (in part) by a California DivisionAmerican Cancer Society fellowship (S-42-94) to M.S. and by a National Institutes of Health grant (GM23441-19) to D.K.

The publication costs of this article were defrayed in part by payment of page charges. This article must therefore be hereby marked "advertisement" in accordance with 18 USC section 1734 solely to indicate this fact.

\section{References}

Bassler, B.L., M. Wright, and M.R. Silverman. 1994. Sequence and function of LuxO, a negative regulator of luminescence in Vibrio harveyi. Mol. Microbiol. 12: 403-412.

Block, R. and W.A. Haseltine. 1975. Purification and properties of stringent factor. J. Biol. Chem. 250: 1212-1217.

Bretscher, A.P. and D. Kaiser. 1978. Nutrition of Myxococcus xanthus, a fruiting myxobacterium. I. Bacteriol. 133: 763 768.

Campos, J.M., J. Geisselsoder, and D.R. Zusman. 1978. Isolation of bacteriophage $\mathrm{Mx} 4$, a generalized transducing phage for Myxococcus xanthus. J. Mol. Biol. 11: 167-178.

Cashel, M. and K.E. Rudd. 1987. The stringent response. In Escherichia coli and Salmonella typhimurium: Cellular and molecular biology (ed. F.C. Neidhardt, K.B. Low, B. Magasanik, M. Schaechter, and H.E. Umbarger), vol. 2, pp. 1410-1438. ASM Press, Washington D.C.

Dworkin, M. 1962. Nutritional requirements for vegetative growth of Myxococcus xanthus. I. Bacteriol. 288: 250-257.

Dworkin, M. and S.M. Gibson. 1964. A system for studying microbial morphogenesis: Rapid formation of microcysts in Myxococcus xanthus. Science 146: 243-244.

Dworkin, M. and D. Kaiser. 1985. Cell interactions in myxobacterial growth and development. Science 230: 18-24.

Eberhard, A. 1972. Inhibition and activation of bacterial luciferase synthesis. I. Bacteriol. 109: 1101-1105.

Freese, E.B., N. Vasantha, and E. Freese. 1979. Induction of sporulation in developmental mutants of Bacillus subtilis. Mol. \& Gen. Genet. 170: 67-74. 
Fuqua, W.C., S.C. Winans, and E.P. Greenberg. 1994. Quorum sensing in bacteria: The LuxR-LuxI family of cell densityresponsive transcriptional regulators. I. Bacteriol. 176: 269275.

Gill, R.E. and L.J. Shimkets. 1993. Genetic approaches for analysis of myxobacterial behavior. In Myxobacteria II led. M. Dworkin and D. Kaiser), pp. 129-156. ASM Press, Washington D.C.

Gulati, P., D. Xu, and H.B. Kaplan. 1995. Identification of the minimum regulatory region of a Myxococcus xanthus A-signal-dependent developmental gene. J. Bacteriol. (in press).

Hodgkin, J. and D. Kaiser. 1979. Genetics of gliding motility in Myxococcus xanthus (Myxobacterales): Two gene systems control movement. Mol. \& Gen. Genet. 171: 167-176.

Hodgson, D.A. 1993. Light-induced carotenogenesis in Myxococcus xanthus: Genetic analysis of the carR region. Mol. Microbiol. 7(3): 471-488.

Inouye, M., S. Inouye, and D.R. Zusman. 1979. Biosynthesis and self-assembly of protein $\mathrm{S}$, a development-specific protein of Myxococcus xanthus. Proc. Natl. Acad. Sci. 76: 209-213.

Kaiser, D. 1989. Multicellular development in myxobacteria. In Genetics of bacterial diversity (ed. D.A. Hopwood and K.F. Chater), pp. 243-263. Academic Press, New York.

Kalman, L.V., Y.L. Cheng, and D. Kaiser. 1994. The Myxococcus $x a n t h u s d s g$ gene product performs functions of translation initiation factor IF3 in vivo. J. Bacteriol. 176: 1434-1442.

Kaplan, H.B., and E.P. Greenberg. 1985. Diffusion of autoinducer is involved in regulation of the Vibrio fischeri luminescence system. J. Bacteriol. 163: 1210-1214.

Kaplan, H.B., A. Kuspa, and D. Kaiser. 1991. Suppressors that permit A-signal independent developmental gene expression in Myxococcus xanthus. I. Bacteriol. 173: 1460-1470.

Keseler, I.M. and D. Kaiser. 1995. An early A-signal-dependent gene in Myxococcus xanthus has a ${ }^{54}$ like promoter. I. Bacteriol. (in press).

Kroos, L. 1986. "Cell interactions govern gene expression during Myxococcus development." Ph.D. thesis, Department of Biochemistry, Stanford University, Stanford, CA.

Kroos, L. and D. Kaiser. 1984. Construction of Tn5lac, a transposon that fuses lac $Z$ expression to exogenous promoters, and its introduction into Myxococcus xanthus. Proc. Natl. Acad. Sci. 81: 5816-5820.

Kroos, L., A. Kuspa, and D. Kaiser. 1986. A global analysis of developmentally regulated genes in Myxococcus xanthus. Dev. Biol. 117: 252-266.

- 1987. Expression of many developmentally regulated genes in Myxococcus depends on a sequence of cell interactions. Genes \& Dev. 1: 840-854.

- 1990. Defects in fruiting body development caused by Tn5lac insertions in Myxococcus xanthus. I. Bacteriol. 172: 484-487.

Kuspa, A., L. Kroos, and D. Kaiser. 1986. Intercellular signaling is required for developmental gene expression in Myxococcus xanthus. Dev. Biol. 117: 267-276.

Kuspa, A., L. Plamann, and D. Kaiser. 1992a. Identification of heat-stable A-Factor from Myxococcus xanthus. I. Bacteriol. 174: 3319-3326.

. 1992b. A-signalling and the cell density requirement for Myxococcus xanthus development. J. Bacteriol. 174: 73607369.

Levine, A., F. Vannier, M. Dehbi, G. Henckes, and S.J. Séror. 1991. The stringent response blocks DNA replication outside the ori region in Bacillus subtilis and at the origin in Escherichia coli. J. Mol. Biol. 219: 605-613.

Li, S., B. Lee, and L.J. Shimkets. 1992. $\operatorname{csg} A$ expression entrains
Myxococcus xanthus development. Genes \& Dev. 6: 401-410. Lopez, I.M., C.L. Marks, and E. Freese. 1979. The decrease of guanine nucleotides initiates sporulation of Bacillus subtilis. Biochim. Biophys. Acta 587: 238-252.

Lopez, J.M., A. Dromerick, and E. Freese. 1981. Response of guanosine- 5 '-triphosphate concentration to nutritional changes and its significance for Bacillus subtilis. J. Bacteriol. 146: 605-613.

Manoil, C.C. 1982. "Initiation of the development of Myxococcus xanthus." Ph.D. thesis, Department of Biochemistry, Stanford University, Stanford, CA.

Manoil, C. and D. Kaiser. 1980a. Accumulation of guanosine tetraphosphate and guanosine pentaphosphate in Myxococcus xanthus during starvation and myxospore formation. I. Bacteriol. 141: 297-304.

- 1980b. Guanosine pentaphosphate and guanosine tetraphosphate accumulation and induction of Myxococcus xanthus fruiting body development. J. Bacteriol. 141: 305-315.

Marsh, J.L., M. Erfle, and E.J. Wykes. 1984. The pIC plasmid and phage vectors with versatile cloning sites for recombinant selection by insertional inactivation. Gene 32: 481-485.

Martin, S., E. Sodergren, T. Masuda, and D. Kaiser. 1978. Systematic isolation of transducing phages for Myxococcus xanthus. Virology 88: 44-53.

Metzger, S., I.B. Dror, E. Aizenman, G. Schreiber, M. Toone, J.D. Friesen, M. Cashel, and G. Glaser. 1988. The nucleotide sequence and characterization of the relA gene of Escherichia coli. J. Biol. Chem. 263: 15699-15704.

Nealson, K.H., T. Platt, and J.W. Hastings. 1970. Cellular control of the synthesis and activity of the bacterial luminescent system. I. Bacteriol. 104: 313-322.

Nelson, D.R. and K.P. Killeen. 1986. Heat shock proteins of vegetative and fruiting Myxococcus xanthus cells. J. Bacteriol. 168: 1100-1106.

Ochi, K., J. Kandala, and E. Freese. 1982. Evidence that Bacillus subtilis sporulation induced by the stringent response is caused by the decrease in GTP or GDP. I. Bacteriol. 151: 1062-1065.

O'Connor, K.A. and D.R. Zusman. 1988. Reexamination of the role of autolysis in the development of Myxococcus xanthus. I. Bacteriol. 170: 4103-4112.

Orndorff, P.E., E. Stellwag, T. Starich, M. Dworkin, and J. Zissler. 1983. Genetic and physical characterization of lysogeny by bacteriophage $\mathrm{Mx} 8$ in Myxococcus xanthus. $J$. Bacteriol. 154: 772-779.

Schreiber, G., S. Metzger, E. Aizenman, S. Roza, M. Cashel, and G. Glaser. 1991. Overexpression of the relA gene in Esche. richia coli. I. Biol. Chem. 266: 3760-3767.

Stellwag, E., J.M. Fink, and J. Zissler. 1985. Physical characterization of the genome of the Myxococcus xanthus bacteriophage Mx8. Mol. \& Gen. Genet. 199: 123-132.

Straus, D.B., W.A. Walter, and C.A. Gross. 1987. The heat shock response of $E$. coli is regulated by changes in the concentration of $\sigma^{32}$. Nature 329: 348-351.

Wireman, J.W. and M. Dworkin. 1977. Developmentally induced autolysis during fruiting body formation by $M y x O c o c-$ cus xanthus. I. Bacteriol. 129: 796-802.

Yajko, D.M. and D.R. Zusman. 1978. Changes in cAMP levels during development of Myxococcus xanthus. I. Bacteriol. 133: $1540-1542$. 


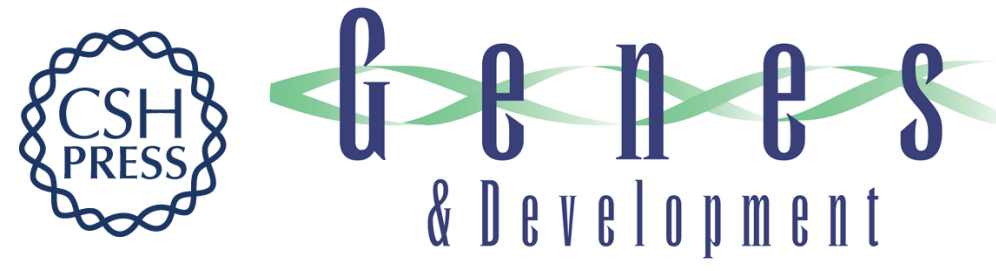

\section{Ectopic production of guanosine penta- and tetraphosphate can initiate early developmental gene expression in Myxococcus xanthus.}

$M$ Singer and D Kaiser

\section{Genes Dev. 1995, 9:}

Access the most recent version at doi:10.1101/gad.9.13.1633

References This article cites 42 articles, 27 of which can be accessed free at:

http://genesdev.cshlp.org/content/9/13/1633.full.html\#ref-list-1

License

Email Alerting

Service

Receive free email alerts when new articles cite this article - sign up in the box at the top right corner of the article or click here.

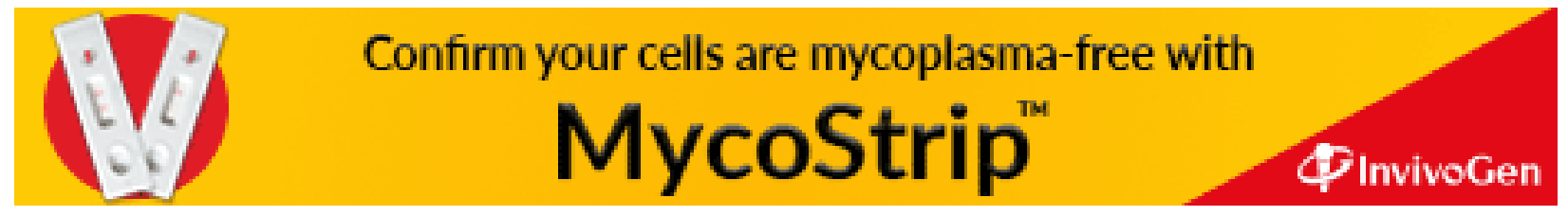

